\title{
PREPARATION OF JUNIPERUS EXTRACT AND DETECTION OF ITS ANTIMICROBIAL AND ANTIOXIDANT ACTIVITY
}
R. K. Maeh ${ }^{1}$
A.I.Jaaffar ${ }^{2}$
Lecturer
Assist. Lecturer
K.F.AL-azawi ${ }^{3}$
Assist. Prof.

\section{College of density/ University of AL IRAQIA}

raghadnoor79@gmail.com_ahmedissa2002@yahoo.com 100122@uotechnology.edu.iq

\section{ABSTRACT}

This study was aimed to produce silver nanoparticles by fruits extract of Juniperus phoenicea and comparison between the ethanolic extract and nano extract through the antioxidant, antibacterial, anti-parasite and cytotoxicity against prostate cancer. The synthesis of silver nanoparticles was shown by many characterizing techniques: UV, FTIR, XRD and SEM. Nano extract exhibited a higher antibacterial, antioxidant, antiparasite compared to ethanolic extract and higher cytotoxicity activity. The nano extract exhibited higher antibacterial activity compared with antibiotics. Finally, we study the toxicity of $J$. phoenicea by Inhibition of $\mathrm{RBC}$ hemolysis by $\mathrm{H}_{2} \mathrm{O}_{2}$, the results exhibited the highest inhibition activity of J. phoenicea against $\mathrm{H}_{2} \mathrm{O}_{2}$. The nanoextract of $J$. phoenicea can be used effectively in the production of potential antioxidant, antiparasite antimicrobial and anticancer.

Keywords: eco-friendly, silver nanoparticles, Juniperus phoenicea ,anticancer, antioxidant, antimicrobial.

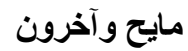

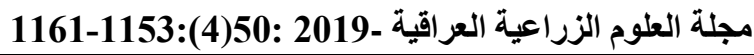
تحضير مستخلص العرعر والكشف عن فعاليته الضد مايكروبيه ونشاطه المضاد للاكسدة

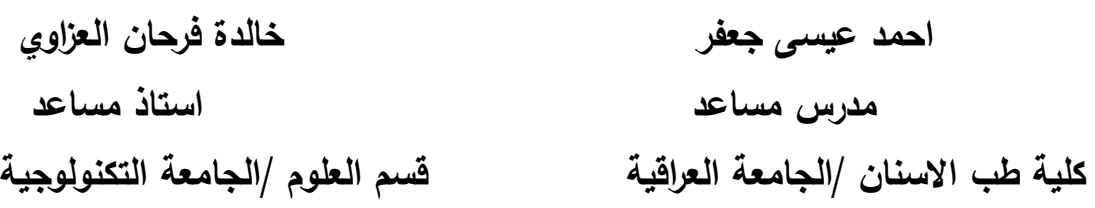

هدفت الاراسة الحالية لتكوين جسيمات الفضة النانوية بواسطة مستخلص ثمار العرعر الفينيقي والمقارنة بين المستخلص الكحولي والنانوي من خلال النشاط المضاد للاكسدة ,المضاد للبكتريا ,المضاد للطقيليات والسمية الخلوية ضد سرطان البروستات. تم التأكد من تخليق الجسيمات النانوية من خلال أستعمال تقتيات تشخيصية متعدده مثل تقنية طيف الامتصاص

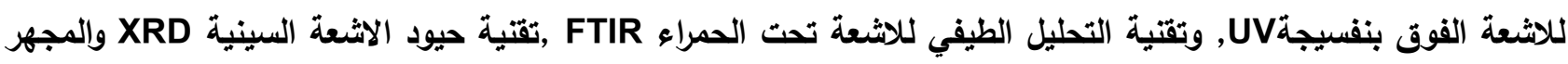
الاكتروني الماستSEM.اظهر المستخلص النانوي له فعالية اكثر من المستخلص الكحولي في النشاط المضاد للبكتريا

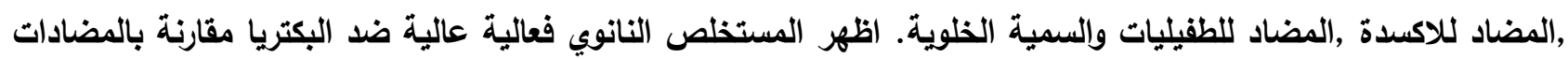

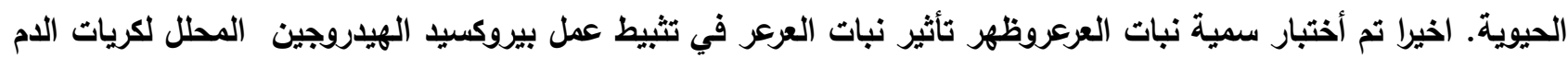
الحمراء. يمكن استخدام المستخلص النانوي لثمار العرعر كعامل قوي مضاد للاكسدة والطقيليات والبكتريا ومضاد للسرطان. الكلمات المفتاحية: طريقة صديقة للبيئة, جسيمات الفضة النانوية، نبات العرعز الفينيقي، مضاد للسرطان، مضادة للاكسدة، النشاط الضد مايكرويي. 


\section{INTRODUCTION}

Plants were used a source of treatment diseases in most parts of the world $(6,9)$. The genus Juniperus followed to Family Cupressaceae $(1,10)$. Juniperus is a great antioxidant fruit, which is used in some popular medicinal systems to treat a diversity of diseases such as gout, arthritis and rheumatism (1). New studies were observed the inhibitory action of Juniperus against Staphylococcus aureus, Escherichia coli, Listeria monocytogenes Bacillus cereus, Cornybacterium spp and with an extended panel of pathogenic bacteria $(11,24)$. Plant parts such as bark, seed, stem, fruit, and leaf extracts have been successfully used for synthesis of nanoparticles (3). Silver nanoparticles have been used extremely due to their potent, antitumor, antifungal, and antibacterial activity (16). The silver nanoparticles have been widely used in preservation, cosmetics, food packaging and medicine $(3,16)$. In the group of medicinal plants, the Juniperus have medicinal properties and taken into account for the synthesis of silver nanoparticles (1). The synthesized silver nanoparticles are characterized by SEM, XRD, UV and FTIR analysis. Plants have an amount of poly flavonoids and phenols, which used to the reduction of silver ions. These poly flavonoids and phenols are used as antioxidant and antimicrobial agents by the plants to protect themselves from several pathological conditions $(11,24)$. Many plants are familiar as sources of natural antioxidants and thus play an essential role in the chemoprevention of aging and diseases $(1,10)$. Between the plants studied to date, one display enormous potential is the Juniperus phoenicea. The present study was aimed to produce silver nanoparticles from fruits extract of Juniperus phoenicea and comparison between the ethanolic extract and nano extract through the antioxidant , antibacterial ,antiparasite and cytotoxicity against prostate cancer cell line in vitro, also examiend the combined effect of some antibiotics and nanoextract against some pathogenic bacteria. Furthermore, was study the toxicity of Juniperus phoenicea by Inhibition of RBC hemolysis caused by $\mathrm{H}_{2} \mathrm{O}_{2}$.

\section{MATERIALS AND METHODS \\ Juniperus Fruits and the extraction}

Dry fruits of Juniperus were collected, washed in distilled water and dried by air-drying. Fifty gms of powdered fruits were extracted with ,ethanol $300 \mathrm{ml}(70 \%)$ for $7-14 \mathrm{hrs}$ by Soxhlet apparatus method. Then the extract was evaporated to dryness and stored in a freeze until used (3).

\section{Microbial strains}

The pathogens strains were provided by microbiology lab, science department, university of technology in Baghdad these: Pseudo. aerugenosa, staph. aureus, and Candida albicans.

\section{Silver nanoparticles}

Ten milliliters of the extract were mixed with $90 \mathrm{~mL}$ of $0.01 \mathrm{mmol} / \mathrm{mL}$ aqueous $\mathrm{AgNO} 3$ and display to sunlight for $1 \mathrm{~h}$. A modification from yellowish to reddish brown color was noticed (3).

\section{Antibacterial activity}

The ethanolic and nano extract of Juniperus were established through, agar well diffusion technique against $S$. aureus $(\mathrm{G}+), C$. albicans (yeast), and $P$. aeruginosa (G-). the clean cultures of the microbes were subculture on MHA the quantity of each bacterial suspension was balanced to that of 106 $\mathrm{CFU} / \mathrm{ml}$ standardized by $0.5 \mathrm{McF}$ arland standard and used as the inoculums for performing agar well diffusion test, Then wells were formed on plates in gel puncture. $50 \mu \mathrm{l}$, of sample $20,40,60$ and $80 \mathrm{mg}$, concentration, one-to-one was transferred on to each well on all plates then, incubation $\{$ at $37^{\circ} \mathrm{c}$ \}for 24 hours, and the diameter of effective zone was estimated in $\mathrm{mm}$ then, The tests plates were done in triplicate (24).

\section{Antioxidant activity}

Estimation of antioxidant activity (radical scavenging activity) was showed by D.P.P.H:(1,1-Diphenyl-2-picrylhydrazyl).

D.P.P.H $4.3 \mathrm{mg}$ has thawed $3.3 \mathrm{ml}$ in ethanol then, its saved safely from light with cover the test tubes using aluminum foil. The next concentrations of Juniperus extracts were prepared 40,80,160 $\mu \mathrm{g} / \mathrm{mL}$ with three replicates per concentration $25 \mu \mathrm{L}$ of each concentration was full with an amount of ethanol until it became $500 \mu \mathrm{L}$ and then over with $500 \mu \mathrm{L}$ of DPPH and incubated at $37^{\circ} \mathrm{C}$ 
for $30 \mathrm{~min}$. The absorbance at517 $\mathrm{nm}$ was then measured through the next calculation (15). Scavenging effect $\%=\left[\left(A_{O D}-B O D\right) / A_{O D}\right]$ * 100

$\mathrm{A}_{\mathbf{O D}}=$ Optical density control,

$\operatorname{bod}=$ optical density sample

\section{Accounts of nanoparticles}

Created

nanoparticles were checked by UV, FTIR, SEM, and XRD. UV-Vis spectral analysis and tested by using spectrophotometer (TechcompUV2300). FTIR, an analysis showed the possible naturally appear organic molecules. XRD sizes of the Ag nanoparticles solution drop-coated on glass and prepared on a Shimadzu XRD-6000 model with (40 kV 30 $\mathrm{mA}$ with $\mathrm{Cu} \mathrm{k} \alpha$ radiation). The crystallite domain size was intended from the width of the XRD peaks and by the Scherer formula :( $\mathrm{D}=0.94 \lambda / \beta \operatorname{Cos} \theta$.)(14).

\section{Maintenance of cell cultures}

The prostate cancer cell line was got by the Iraqbiotechcellbank unit then, kept in RPMI1640 improved by $100 \mu \mathrm{g} / \mathrm{mL}$ streptomycin, 100 units/mL penicillin, and10\% Fetal bovine. We passaged the cell by, Trypsin EDTA ,reseeded in $50 \%$, convergence double in a week then, incubated on $37^{\circ} \mathrm{C}(20)$.

\section{Cytotoxicity Assays}

Cytotoxic effect was determined by MTT assay. MTT, cell activity evaluation was regulated on 96well plates. We seeded cell lines in, $1 \times 104$ cells/well. After 24 , cells were held with the proved complex. Cell activity was tested after 72 hour by discard the medium, addition $28 \mu \mathrm{L}$ of $2 \mu \mathrm{mg} / \mathrm{mL}$ from MTT, and incubation for 1.5 hour at $37{ }^{\circ} \mathrm{C}$. After discard the M.T.T solution, the crystals often residual in the wells, were solubilized with $130 \mu \mathrm{L}$ of Dimethyl Sulphoxide by $37^{\circ} \mathrm{C}$ incubation for $15 \mathrm{~min}$ with shaky (12). The absorbance was estimated on a micro plate reader at $492 \mathrm{~nm}$. The test was worked in triplicate. The effective level was determined by the following calculation:-

Inhibition rate $=[\mathrm{A}-\mathrm{B} / \mathrm{A}] * 100$

$\mathrm{A}$ and $\mathrm{B}$ are the optical density of control and test,

\section{Antiparasite activity}

MTT assay was used to estimate the antiparasitic effects of ethanolic and nano extract of Juniperus against amastigote forms of Leishmania tropica. In the beginning, $100 \mu \mathrm{L}$ of the amastigote (106 cells/mL) harvested from a logarithmic growth phase were additional to 96-well tissue culture plate by RPMI medium 1640. After that, $100 \mu \mathrm{L}$ of tested material was added to every well and incubated at $25 \pm 1^{\circ} \mathrm{C}$ for $48 \mathrm{hrs}$ then, $10 \mu \mathrm{L}$ of MTT solution was added per well and the microtiter plate was incubated for $4 \mathrm{hrs}$ at $25^{\circ} \mathrm{C}$. The media was then detached and 100 $\mu \mathrm{L}$ of DMSO solution was added to solubilize the formazan crystals. Amastigote was cultured at whole medium with no drug as the positive control and whole medium with no amastigote and drugs as blank. The absorbance was measured for all William $492 \mathrm{~nm}$ using an ELISA reader (18). The cytotoxicity can be designed by the following parameters. Inhibition rate $\%=[(\mathrm{A}-\mathrm{B} / \mathrm{A})] \mathrm{X} 100$ Where $\mathrm{A}$ is the optical density of control and $\mathrm{B}$ is the optical density of treated sampl.

Inhibition of erythrocyte hemolysis by hydrogen peroxide

Venous blood was collected from a healthy person and then supplied into heparinized tubes. the blood was centrifuged in $1000 \mathrm{rpm}$ to $15 \mathrm{~min}$, then washed 3 times by phosphate buffered saline $(0.2 \mathrm{M}, \mathrm{pH} 7.4)$, then suspended in the similar buffer to the desired hematocrit level. A portion of erythrocyte 200 $\mu \mathrm{L}$ was transported into a test tube with $100 \mu \mathrm{L}$ of hydrogen peroxide $(100 \mu \mathrm{M})$ for inducing hemolysis. The tested compounds $200 \mu \mathrm{L}$ were added with softly swirled and incubated for $3 \mathrm{hr}$ at $37{ }^{\circ} \mathrm{C}$. PBS $8 \mathrm{~mL}$ was added then the solution was centrifuged on a speed $3000 \mathrm{rpm}$ for $10 \mathrm{~min}$. The absorbance of the contents was tested at $540 \mathrm{~nm}$ (23). The inhibition of hemolysis was calculated to the following equation:

Scavenging $=[\%$ Absorbance of control Absorbance of sample $\backslash$ Absorbance of control ]X100\%

\section{RESULTS AND DISCUSSION UV analysis}

The silver nanoparticles biosynthesis was checked using UV- visible spectroscopy. The fruit Juniperus extract was yellowish in next color, adding of $\mathrm{AgNo}_{3}$ solution and display to the sun for one hour, then turned brown (Fig. 1). the Ag external Plasmon resonance band at 413 nm. (Fig. 2). 


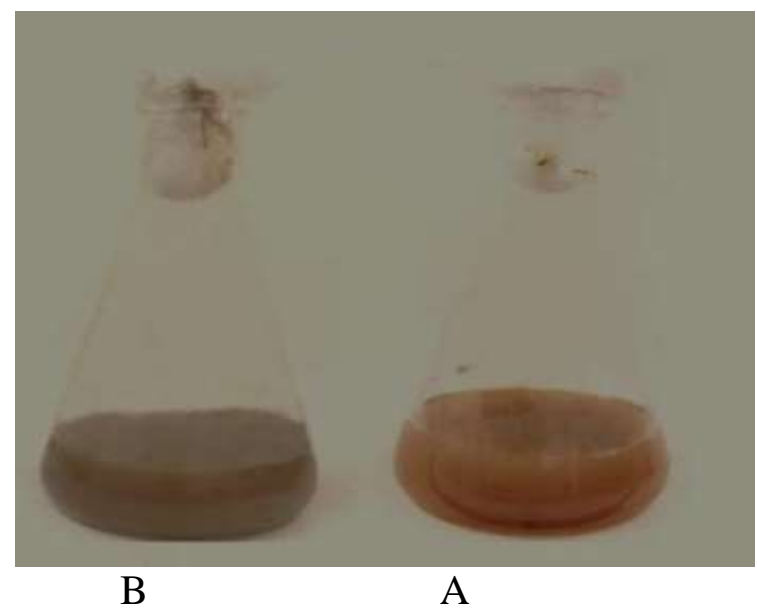

Figure 1. formation of silvernanoparticles by Juniperus A- $\mathrm{AgNo}_{3}$ with Juniperus BColor altered by sunlight

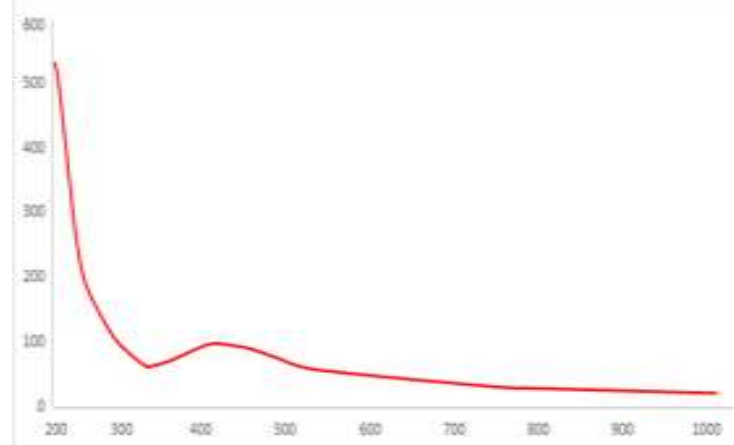

Figure 2. UV-visible spectrums of Juniperus nano extract

\section{Character of nanoparticales by SEM}

The SEM, explanation the shape of nanoparticles, The Fig.3, displays spherical form.

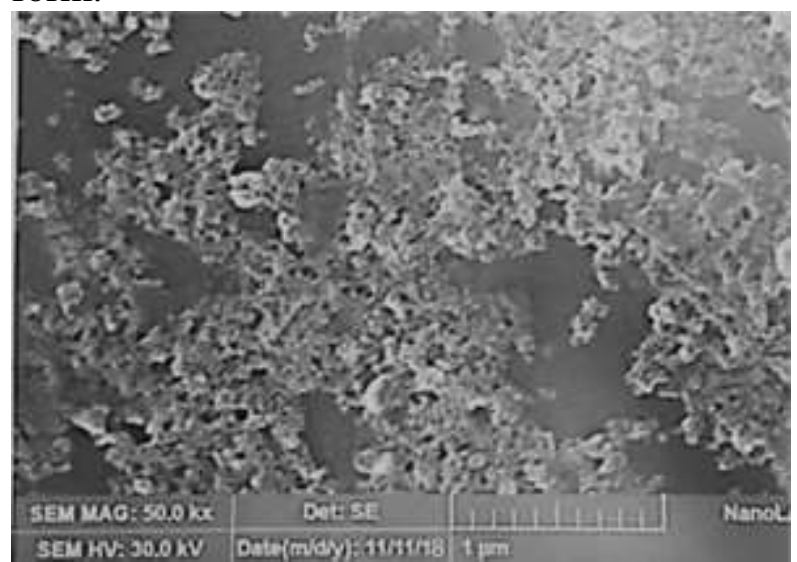

Figure 3. SEM image for Juniperus nano extract

X-Ray diffraction XRD analysis

$\mathrm{X}$-ray diffraction (XRD) is a popular analytical technique which has been used for the analysis of both molecular and crystal structures. The XRD shape showed three intense peaks $(33,38$ and 40) in the whole spectrum of $2 \theta$ value ranging from 20 to 70 and indicated that the structure of silver nanoparticles is facecentered cubic (FCC).These are corresponding to 111 and 200 planes for silver, respectively. The average grain size of the silver nanoparticles formed in the bio reduction process was determined using Scherer's formula and was estimatedat38nm.

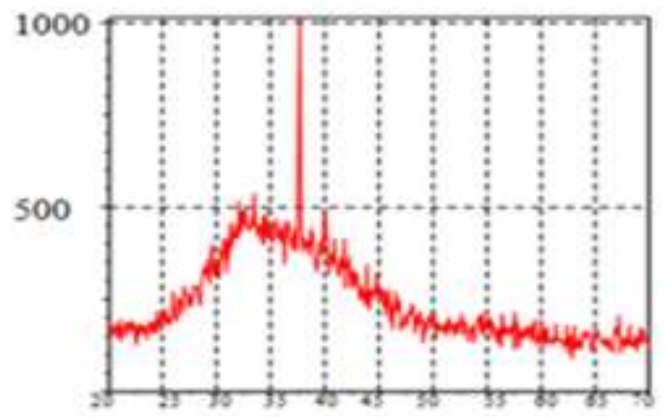

Figure 4. X-ray diffraction analysis for Juniperus nano extract

\section{FTIR for ethanolic and nanoextract}

The FTIR is give the active groups. The ethanolic extract of juniperus displayed the bands at $3390.91 \mathrm{~cm}-1$ due to of phenolic $\mathrm{OH}$. The band at $2928.11 \mathrm{~cm}-1$ as a result of $\mathrm{C}-\mathrm{H}$. The band at $1708.90 \mathrm{~cm}-1$ as a result of $\mathrm{C}=\mathrm{O}$. The band at 1619.61due to $\mathrm{C}=\mathrm{C}$. The band at, $1516.19,1454.28,1342.51 \mathrm{~cm}-1$ as a result of $\mathrm{C}-\mathrm{H}$.the band at $1147.60,1033.80,1232.52$ as a result of C-O (4), while the FTIR for nano extract exhibited the same result except for absence the bands at 1147.60 because of reduction of silver ions(4)as shows in $\operatorname{Fig}(5,6)$.

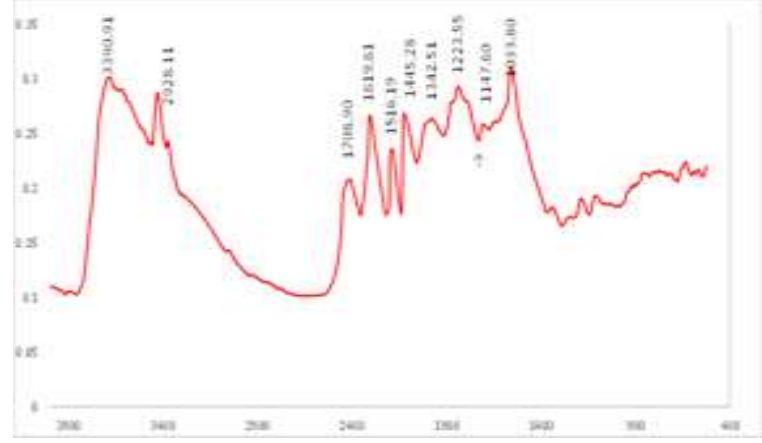

Figure 5. FTIR spectrum for Juniperus ethanolic extract

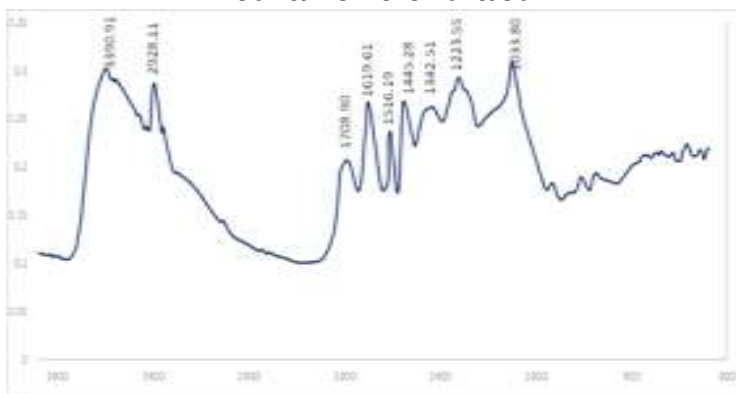

Figure 6. FTIR spectrum for Juniperus nano extract 
Antimicrobial test of an ethanolic and nano fruit extract of Juniperus

Antimicrobial activity of Juniperus ,fruit extract (ethanolic and nanoextract) against three kinds of microorganisms was estimated. The nanoextract showed larger antimicrobial activity compared to ethanolic extract, (Fig,7, $8)$. The ethanolic extract effect on the growth of p.aeruginosa, S. aureus, and C. albicans, by $14 \mathrm{~mm}, 13 \mathrm{~mm}$ and $10 \mathrm{~mm}$, respectively , While the nano extract $20 \mathrm{~mm}$, $19 \mathrm{~mm}$ and $11 \mathrm{~mm}$ respectively ( Fig. 7,8).

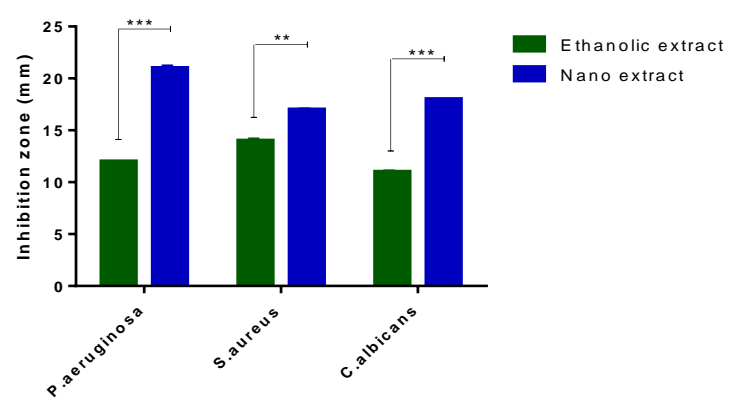

Figure 7. Activity of ethanolic and nanoextract on the growth of bacterial strains, the values represents the Mean \pm $\mathbf{S . E} * * \mathbf{P}<\mathbf{0 . 0 1}, * * * \mathbf{P}<\mathbf{0 . 0 0 1}$

The antimicrobial activity of the silver nanoparticles could be credited to the existence of specific phytochemical components of the ethanolic extract as shown by the FTIR spectra, such as flavonoids, phenolics, tannins, and alkaloids are known to have an anti-inflammatory, antifungal, and antimicrobial effect (19). The nano extract showed larger antimicrobial activity compared to ethanolic extract and the effect of nano extract was more signal against bacteria G-ve than bacteria $\mathrm{G}+\mathrm{ve}$, could be due to the changes of the cell wall structure between Gve and G+ve bacteria(11,24). The studies recommend that the silver ion can effect on phosphorus and sulfur, thus $\mathrm{Ag}+$ can relate with phosphorus moieties in DNA and rises DNA modification furthermore, Microbial cell membrane having an abundance of sulfur proteins, silver ion can rejoin by sulfur having. amino acids and affects microbial cell viability $(13,25)$.

\section{A $\quad$ B $\mid$}
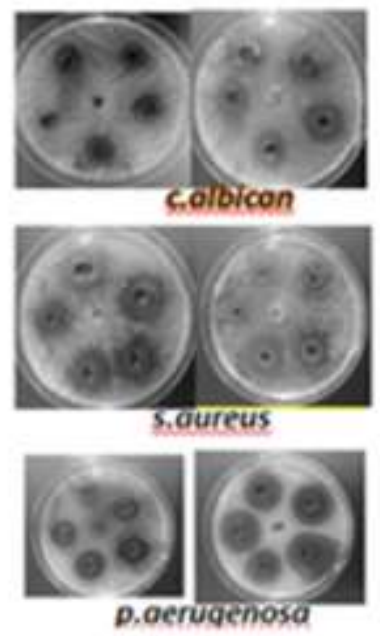

Figure 8. Inhibition zone effects of Juniperus. A- ethanolic extract and nano extract. 10, 20, 40, 60, and $80 \mathrm{mg}$ per $\mathrm{ml}$, concentration respectively, $A$ : ethanolic extract B: nano extract

\section{Antimicrobial activity of antibiotics}

Disc diffusion method was used for estimating the synergistic effect of nano extract of Juniperus with antibiotics against, bacteria, the Juniperus nanoextract was diverted with antibiotics Amoxicillin and Gentamycinconcentrationat $10 \mu \mathrm{g} / \mathrm{ml}$. Results in table (1) shows a combination of nanoextract with antibiotics exhibited synergistic effect against tested bacteria, A,A amoxicillin, with nano extract displayed a rise in its activity: P.aerugenosa before (R,resistance) to $(8 \mathrm{~mm})$, while S.aureus. before (R) to $(12 \mathrm{~mm}), \mathrm{G}$. Gentamycin with nano extract showed an increase in its antimicrobial against, P.aerugenosa from (R) to $(9 \mathrm{~mm})$. While with S.aureus from $(\mathrm{R})$ to $(10 \mathrm{~mm})$. This synergistic result, due to the reaction between antibiotics and nanoparticles, The differences in the cell wall building between gram positive and gram negative bacteria could be due to describe why gram positive bacteria extra sensitive than gram negative bacteria (28). The gram negative have an outside polysaccharide sheath holding the building all polysaccharide mixtures this indications the sheath to high resistible for lipophilic solutes, but gram positive, have one an outer peptidoglycan layer (28). There are several hypotheses could be describe the apparatuses of the synergistic effect, Gentamycin and amoxicillin can destroy bacteria. If bacteria have resistance, another antibacterial agent would destroy the 
bacteria. The synergistic effect affected by a rejoinder among antibiotic and nanoparticles $(17,21)$. Antibiotic particles have numerous effective groups like hydroxy and amido collections. These collections rejoin by nanoparticles through chelation. Antibiotic particles bind each other by van der Waals communication, also further weak bonds(17) The antimicrobial collections come into being, which is join of a nanoparticles core and the antibiotic particles, When antimicrobial particles effect on the surface of bacteria they reason damage. Therefore, the process of antimicrobial particles making is really that of, increasing the antimicrobial agent's concentration $(17,21,28)$

Table 1. Antimicrobial activity of antibiotics and combination of nano extract with antibiotics

\begin{tabular}{|lrrrr|}
\hline & \multicolumn{4}{c|}{ Inhibition Zone (mm) } \\
\hline Microorganizime & A & A+N & G & G+N \\
Staph. aureus & R & 12 & R & 10 \\
Pseudo aeruginos & R & 8 & R & 9 \\
a & & & & \\
\hline
\end{tabular}

N,nanoextract:A,Amoxiciline:G,GentamycnR. Resistance

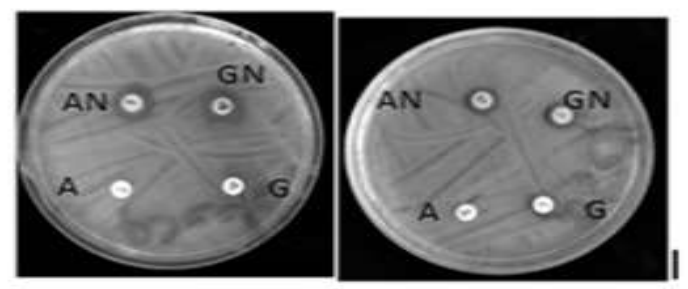

Staphaureus

psederecuginose

Figure 9. Combined effect of antibiotics and nano extract of Juniperus against. Some pathogens. N, nano extract, A, A moxiciline, G, Gentamycin

Antioxidant activity of silver nanoparticles

Antioxidant activity of silver nanoparticles was evaluated through DPPH, free radical scavenging test with Vitamine $\mathrm{C}$ as positive control. DPPH (1, 1-Dpicryl- hydrozyl) is a stable complex, takes hydrogen or electrons from $\mathrm{Ag}$ nanoparticle (25). The outcomes exhibited effective free radical scavenging by Ag nanoparticles and its found that the activity increased with increasing concentrations of AgNPs Fig.(10). AgNPs are recommended to act as electron donors rejoining with free radicals to change them to new stable products, which can terminate radical chain reaction. Furthermore, the reducing power of AgNPs connected well with the radical scavenging activity $(2,22)$. the antioxidant activity of the silver nanoparticles could also be credited to the existence of specific phytochemical components of the ethanolic extract such as phenols, tannin and flavonoids are used for antioxidant(5).

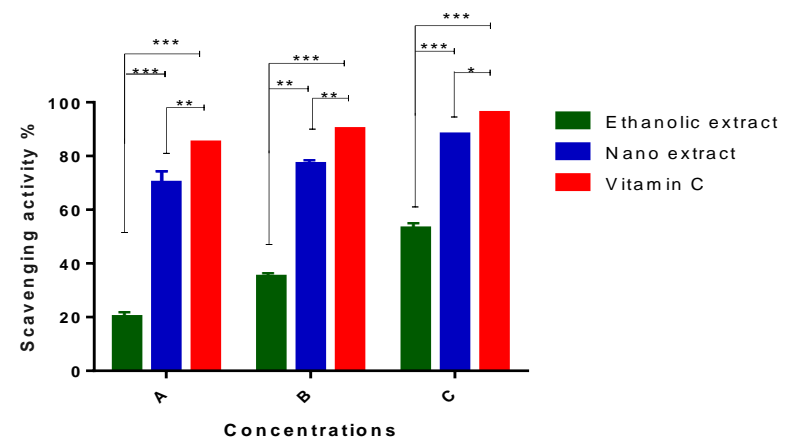

Figure 10. DPPH scavenging activity of ethanolic and nano extract of juniperus. (A) $40 \mu \mathrm{g} / \mathrm{ml}$ (B) $80 \mu \mathrm{g} / \mathrm{ml}$ (C) $160 \mu \mathrm{g} / \mathrm{ml}$. The Mean $\pm \mathbf{S . E} * * \mathbf{P}<\mathbf{0 . 0 1}, * * * \mathbf{P}<\mathbf{0 . 0 0 1}$

Anti parasitic activity

Investigation of the cytotoxic potential of ethanolic and nano extract of Juniperus was showed on amastigote phase of Leishmania tropica. In Fig.11 exhibite the result of cytotoxicity activity. The lowest concentration that causes cytotoxic could be in the 1.25 $\mu$ gmL. Cytotoxic activity of Juniperus increased with increasing concentration. The ethanolic extract of Juniperus presented little inhibiting effects compare with nanoextract of Juniperus displayed highly effective on the parasite, that the cytotoxicity rate reached to $85.65 \%$

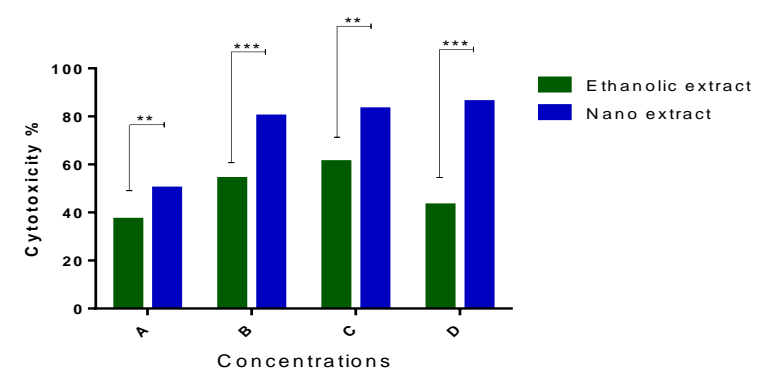

Figure 11. Cytotoxicity effect of Juniperus on L.tropica . (A) $1.25 \mu \mathrm{g} / \mathrm{ml}$ (B) $2.5 \mu \mathrm{g} / \mathrm{ml}$ (C) $5 \mu \mathrm{g} / \mathrm{ml}$ (D) $10 \mu \mathrm{g} / \mathrm{ml}$. the Mean \pm S.E $* * \mathbf{P}<\mathbf{0 . 0 1}, * * * \mathbf{P}<\mathbf{0 . 0 0 1}$

Antileishmanial properties could also be credited to the existence of phenols, flavonoids, alkaloids diterpenes and saponins 
in the Juniperus plant(20).The results confirmed that the nanoextract of Juniperus had inhibitory effects on Leishmania parasites. Several mechanisms have been suggested that nanoparticles are able to induce reactive oxygen species and can destroy pathogenic microbes through a method called respiratory burst mechanism $(13,25)$. The oxidative damage affected by ROS producing and inhibiting the enzyme that is involved in the process of ROS making and affection on Leishmanial persistence. The use of nanoparticles as antiparasite agents will act as a big reservoir then will be responsible for anon-enzymatic source of ROS and destroy the invaded parasite (19,29)

\section{A study of anticancer activity of Juniperus by MTT assay}

The cytotoxic effect of Juniperus nano extract against prostate cancer cell line ( $\mathrm{VCaP}$ ) were examined by MTT assay. The nanoextract exhibited the great level of cytotoxic activity with the IC50 values 40.38 in concentration 50 and $100 \mu \mathrm{g} / \mathrm{mL}$, compared to the concentration of $6.25,12.5,25 \mu \mathrm{g} / \mathrm{ml}$ respectively (Fig12,13). Several phytochemicals, e.g., alkaloids, lignans, phenols, flavonoids, terpenes and steroids have been established to possess prominent cytotoxic properties against cancer cells, detailed the anticancer properties of the flavonoids, which were presented to inactivate carcinogen, arrest the cell cycle, inhibit proliferation, induce apoptosis and differentiate, Prevent oxidation then reversal multidrug resistance $(7,26)$. Earlier readings revealed that various polyphenolic and flavonoids complexes were existing in several Juniperus species Especially, these collections of phytochemicals have been extracted from the berries and leaves of J. phoenicea and other Juniperus species grownup in altered countries $(9,28,30)$. Podophyllotoxin, which is furthermore existing in $J$. phoenicea is a cytotoxic complex against cancer cell lines (1, 31). The cytotoxicity is facilitated through inhibition of microtubule development and this complex helps as a unique starting compound for the semi synthesis of anticancer treatments that are recognized to inhibit topoisomerase II such as teniposide etoposide, or etopophos. $(7,26,27)$. The nano extracts of $J$. showed strong antioxidant activity, determined by measuring the radical scavenging effect on DPPH which may be responsible for its cytotoxic effects.

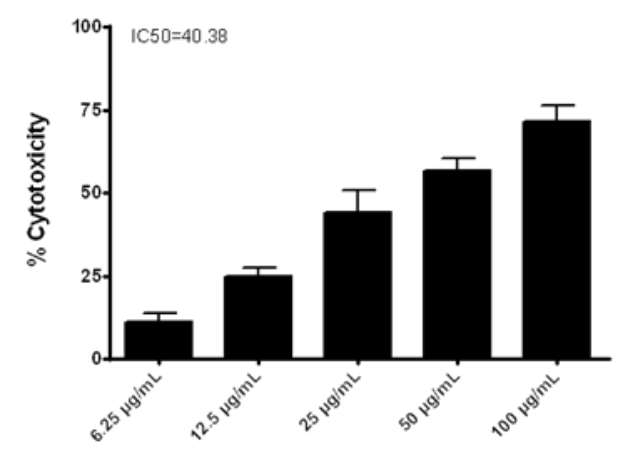

Figure12. Cytotoxic effect of juniperus Nano extract on prostate cancer cell line

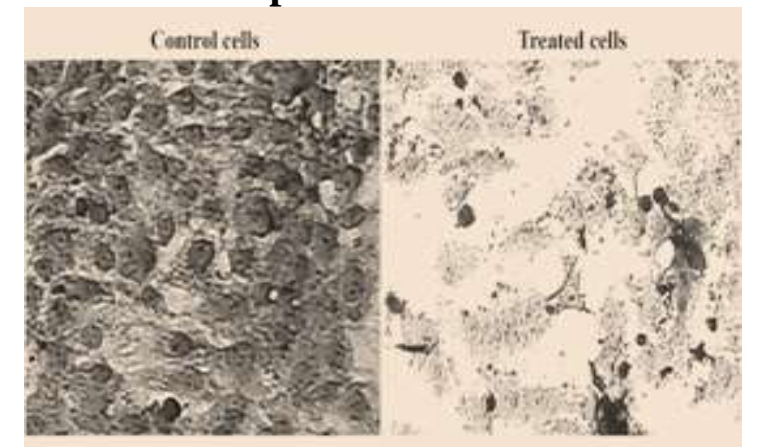

Figure 13. Cytotoxic effect of juniperus nano extract on prostate cancer cell line Inhibition of erythrocyte hemolysis by Hydrogen peroxide

Erythrocytes are a main target for the free radicals due to the high membrane concentration of polyunsaturated fatty acids and the oxygen transport related with redox active hemoglobin molecules, which are strong promoters of activated oxygen species (8). The principle of this test was determined by inhibited the act of hydrogen peroxide which crosses RBC membrane and acts on intracellular moiety and forming ferryl radical or hydroxyl radical through interacting with hemoglobin and initiates a series of reactions resulted in RBC lysis (haemolysis) and discharge hemoglobin in to the supernatant( 30). Fig. 14 indicated that ethanolic extract of juniperius exhibited slightly scavenging activity on $\mathrm{H}_{2} \mathrm{O}_{2}$ at concentration $1.25 \mathrm{mgmL}^{-1}$ that reached to $14 \%$. The scavenging activity at concentration $10 \mu \mathrm{gmL}^{-1}$ exhibited better inhibition activity that the percentage reached to $68 \%$. Because of the ability of Juniperius to trap ROS. $\mathrm{H}_{2} \mathrm{O}_{2}$ to cause damage in 
erythrocyte membranes, thereby protecting them from hemolysis

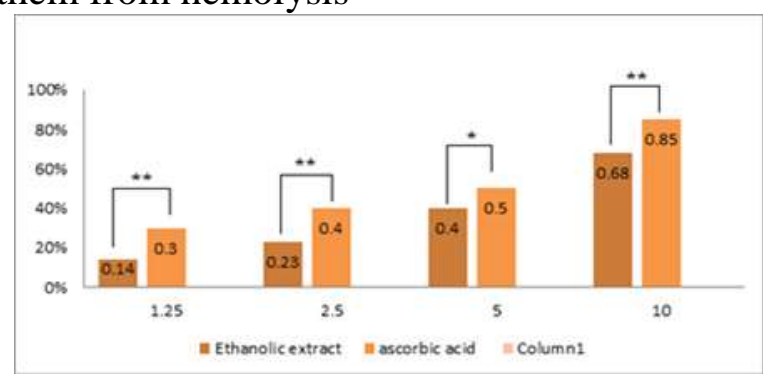

Figure 14. Scavenging activity of juniperus extract on $\mathrm{H}_{2} \mathrm{O}_{2}$

This study was exposed that silver nanoparticles can be synthesized in a simple method using $J$. phoenicea fruit extract. The XRD and SEM analysis exhibited the sizes and shape of the synthesized AgNps. FTIR was used to recognize the biomolecules present in J. phoenicea. UV was examined to recognize the bioreduction of $\mathrm{AgNO}$ to AgNPs. Nanoextract of J. phoenicea showed a higher antioxidant, antimicrobial, antiparasite activity compared to ethanolic extract alone, The combined effect of antibiotics and nanoextract exhibit synergism effect in most kinds of bacteria The $J$. phoenicea nanoextract exhibited strong cytotoxic effects against prostate cancer cell line .J. phoenicea had no toxic effect on blood components. It could be concluded that $J$. phoenicea fruit extract can be used effectively in the production of potential antioxidant, antiparasite antimicrobial and anticancer for commercial application.

\section{REFERENCES}

1. Adams, R. 2004.Juniperus deltoids, a new species, and nomenclatural notes on Juniperuspolycarpos and $J$. turcomanica (Cupressaceae). Phytologia.;86(2):49-53

2. Aqil, F.; I. Ahmed and Z. Mehmood. 2006 Antioxidant and free radical scavenging properties of twelve traditionally used Indian medicinal plants. Turk J Biol.;(30): 177-183

3. Bar, H.; D. K. Bhui;G. P. Sahoo; P. Sarkar; S. Pyne; and A. Misra.2009. Green synthesis of silver nanoparticles using seed extract of Jatropha curcas. Colloids and Surfaces A, 348. 1-3: 212-216

4. Berthomieu, C.and R. Hienerwadel. 2009. Fourier transforms infrared (FTIR) spectroscopy, Journal of Photosynthesis research. 101, 157-170.
5. Blois, M.S. .1958. Antioxidant determinations by the use of a stable free radical. Nature; 181: 1199-1200

6. Cowan, M. 1999. Plant products as antimicrobial agents. Clin. Microbial. Rev., 12(4): 564-582

7. Crowell, P.; S. Lin; E. Vedej and M. Gould. 1992. Identification of metabolites and of the antitumor agent dlimonene capable of inhibiting protein isoprenylation and cell growth. Cancer Chemother Pharmacol. ;31:205-212

8. Ebrahimzadeh, M.; A. Ehsanifar; S. and B. Eslami. 2009. Sambucus ebulus elburensis fruits: A good source for antioxidants, Journal of Pharmacognosy magazine. 5, 213. 161

9. Eisai, P. 1995. Medicinal Herb Index in Indonesia. $2^{\text {nd }}$ Jakarta: Dian Rakyat

10. Farjon, A. 2001.World Checklist and Bibliography of Conifers. $2^{\text {nd }}$ ed.; Royal BotanicalGardens, Kew, London

11. Filipowicz, N.; M. Kaminski and J. Kurlenda. 2003. Antibacterial and antifungal activity of juniper berry oil and its selected components. Phytotherapy Research.; 17(3):227-31

12. Hayon, T.; A. Dvilansky; O. Shpilberg and I. Nathan. 2003 Appraisal of the MTT-based assay as a useful tool for predicting drug chemosensitivity in leukemia, Journal of Leukemia and lymphoma. 44, 1957-1962

13. Holt, K. and A. Bard. 2005. Interaction of silver (I) ions with the respiratory chain of Escherichia coli: an electrochemical and scanning electrochemical microscopy study of the antimicrobial mechanism of micromolar Ag. Biochemistry, 44: 13214-13223

14. Holzwarth, U and N. Gibson 2011. The Scherrer equation versus the'DebyeScherrer equation', Journal of Nature Nanotechnology. 6,534

15. Keser, S.; S. Celik; S. Turkoglu,; O. Yilmaz and I. Turkoglu. 2012. Hydrogen peroxide radical scavenging and total antioxidant activity of hawthorn, Journal of Chemistry 2, 9-12

16. Kokura, S.; O. Handa; T. Takagi; T. Ishikawa; Y. Naito and T.Yoshikawa, 2010. Silver nanoparticles as a safe preservative for use in cosmetics, Nanomedicine, 6(4):570-574 17. Lok, C.; C. Ho; R .Chen; Q. He; W. Yu; H .Sun; P. Tam; J. Chiu and C. Che. 2006. 
Proteomic analysis of the mode of antibacterial action of silver nanoparticles. J Proteome Res, 5: 916-924

18. Mahmoudvand, H.; F. Ezzatkhah; F. Sharififar; I. Sharifi and E. Dezaki. 2015 Antileishmanial and cytotoxic effects of essential oil and methanolic extract of Myrtus communis L, The Korean journal of parasitology. 53, 21

19. Mehta, A.and C. Shaha. 2006. Mechanism of metalloid-induced death in Leishmania spp.the role of iron, reactive oxygen species, $\mathrm{Ca} 2+$, and glutathione, Journal of Free Radical Biology and Medicine. 40, 1857-1868 20. Mueller, H.; M. Kassack and M. Wiese. 2004. Comparison of the usefulness of the MTT, ATP, and calcein assays to predict the potency of cytotoxic agents in various human cancer cell lines, Journal of Biomolecular Screening. 9, 506-515

21. Nascimento, G.; J. Locatelli; P. Freitas and G. Silva. .2000. Antibacterial activity of plant extracts and phytochemicals on antibioticresistant bacteria. Braz.J. Microbiol. 31: 15178382

22. Nie, Z.; K.J. Liu; C.-J. Zhong; L.-F. Wang; Y. Yang; Q. Tian and Y. Liu.2007 Free Radical Biol. Med., 43 1243-1254.

23. Okoko, T. and D. Ere.2012 Reduction of hydrogen peroxide-induced erythrocyte damage by Carica papaya leaf extract, Asian Pacific Journal of Tropical biomedicine. 2, 449-453

24. Pepeljnjak, S.; I. Kosalec and Z. Kalodera. 2005. Antimicrobial activity of juniper berry essential oil (Juniperus communis L., Cupressaceae). Acta Pharmaceutica Zagreb.; 55(4):417

25. Sahayaraj, K. and S. Rajesh.2011.Bionanoparticles synthesis and antimicrobial applications. Palayamkottai $.2: 620$ - 627 .Tamil Nadu, India

26. Skehan, P.and R. Storeng. 1990 .New colorimetric cytotoxicity assay for anticancer drug screening. J Natl cancer Institute. 82:1107-1112

27. Stassi, V.; E. Verykokidou; A. Loukis; C. Harvala and S. Philianos. 1996. The antimicrobial activity of the essential oils of four Juniperus species growing wild in Greece. Flavour and Fragrance Journal; 11:71-74

28. Toroglu, S.2011: In-vitro antimicrobial activity and synergistic/antagonistic effect of interactions between antibiotics and some spice essential oils. J. of Environ. Bio, 32 (1) 23-29

29. Uttara, B.; A. Singh; V. Zamboni and R. Mahajan. 2009 Oxidative stress and neurodegenerative diseases: a review of upstream and downstream antioxidant therapeutic options, Current neuropharmacology. 7, 65-74. 153

30. Welbourn, E.; M. Wilson; T. Yusof; A. Metodiev; M. and C. Cooper. 2017.The mechanism of formation, structure and physiological relevance of covalent hemoglobin attachment to the erythrocyte membrane, Journal of Free Radical Biology and Medicine. 103, 95-106. 162 